\title{
Difference or Indifference: China's Development Assistance Unpacked
}

\author{
Xiaoyun Li, Dan Banik, Lixia Tang and Jin Wu*
}

\begin{abstract}
China's growing role in international development through so-called 'South-South cooperation' has attracted considerable global attention. This article aims to provide a nuanced understanding of the nature of foreign aid policies implemented by China and help facilitate a new set of dialogues between China and more established providers of aid. It unpacks the developmental side of the story by first analysing the official discourse of Chinese aid in a historical context and thereafter examines the practice of conditional aid in relation to the Chinese emphasis on non-interference and mutual interest. The empirical basis for this article is largely derived from field studies undertaken in Malawi, Tanzania and Zimbabwe. We argue that although centrally controlled, Chinese aid has been consistently developmental, reflecting both the country's own development path and, to a lesser extent, international developmental goals.
\end{abstract}

\section{相似与差异：解析中国的对外援助}

李小云, 丹・巴尼克, 唐丽霞, 武晋

中国通过 “南南合作” 对世界发展的影响越来越大, 吸引了国际方面的关注。本文 旨在深入分析中国对外援助政策的实质, 帮助中国与原有的捐助国展开一系列新的 对话。为研究其中的变化, 本文首先分析了不同历史背景下中国关于对外援助的官 方声明，随后研究了有条件援助与中国不干涉他国内政和互利政策的关系。本文的 数据主要来自对马拉维、坦桑尼亚和津巴布韦的实地调查。我们认为, 尽管中国的 对外援助由中央政府决定, 但也是不断发展变化的, 它既反映了中国自身的发展路 线, 也在一定程度上受国际发展目标的影响。

IDS Bulletin Volume 45 Number 4 July 2014 (c) 2014 The Authors. IDS Bulletin (C) 2014 Institute of Development Studies Published by John Wiley \& Sons Ltd, 9600 Garsington Road, Oxford OX4 2DQ, UK and 350 Main Street, Malden, MA 02148, USA 


\section{Introduction}

Riding on an impressive record of rapid economic growth and poverty reduction, China is increasingly influencing social and economic policies around the world. Through so-called 'South-South cooperation', China has become much more assertive in international development, trade, environment and foreign aid policies. Such cooperation gives access to natural resources, new and growing markets, and also reduces the dependence of poor countries on traditional forms of aid from the global North. While China's growing presence on the world stage has attracted considerable scholarly interest, it has also resulted in heated political debates in both developed and developing countries. Particularly singled out for attention has been the Chinese government's growing support for the activities of Chinese state-owned enterprises and private sector actors through the Forum on China-Africa Cooperation (FOCAC). Rather than providing budget support to governments, and conditioning aid on support for civil and political rights, the Chinese model has consistently emphasised the principles of 'win-win', 'mutual respect', 'friendship' and 'noninterference' (Banik 2013). China has further projected the idea that state-to-state relations ought to be beneficial for itself and the aidrecipient country, and conducive to each other's national development. Hence, it has introduced in the public discourse of many African countries terms such as 'complementarity', 'potential' and 'opportunity'.

This article neither seeks to defend China's foreign aid practices nor to criticise Western models. Rather, the aim is to provide a more nuanced understanding of the nature of foreign aid policies implemented by China and to facilitate a new set of dialogues between China and more established providers of aid. We wish to unpack the developmental side of the story by first analysing the official discourse of Chinese aid in a historical context, but with a particular emphasis on Chinese agricultural assistance in Africa.

Thereafter, we examine the practice of conditional aid in relation to the Chinese emphasis on non-interference, followed by a discussion of the idea of altruistic aid interventions in comparison to the Chinese preference for cooperation based on mutual interest. Both these sets of issues have attracted considerable attention in political and academic circles as China seeks to increase its interactions with the international aid architecture. The key questions we address include the following: To what extent does Chinese development assistance represent, and build further on, China's own development experiences based on a set of core principles? And to what extent does the Chinese model differ from established Western approaches over time? Moreover, what are the main sets of development successes and failures that have resulted from Chinese interventions? And how can China and other countries join forces when the goal is shifted from aid effectiveness to development effectiveness? The empirical basis for this article is largely derived from field studies we have previously conducted in Malawi, Tanzania and Zimbabwe in connection with various projects examining Chinese development assistance in Africa. We do not discuss these cases in detail; rather we briefly refer to the experiences of these countries along with several others in Africa to illustrate our argument.

China's foreign aid programme has gradually evolved since the $1950 \mathrm{~s}$, almost coinciding with the evolution of Western foreign aid practices. Despite frequent changes in the modality, scope and volume of aid under different political and economic contingencies, a large part of the current literature on China's foreign aid dominantly ascribes the past as politically motivated and the present as economically driven. Rather, we argue that China's foreign aid, although centrally controlled, has been consistently developmental, reflecting both the country's own development path and, to a lesser extent, international developmental goals.

\section{Literature review}

There has been a growing interest in understanding the implications of China's foreign aid, in particular aid to Africa after 2005. ${ }^{1}$ This increase in scholarly interest derives largely from the concern that China's brand of aid mixed together with other financial flows and market dynamics are making significant impacts on economic growth and development in Africa (Power et al. 2012). The literature, however, appears divided, ranging from optimistic analyses that echo the 'win-win' perspective, to the sceptics who argue that China is essentially interested in securing access to cheap raw materials from African countries and exporting manufactured goods back to these very same countries. 
The pessimists argue that although the activities of China and other non-DAC donors have resulted in major increases in external financial flows to Africa, this does not guarantee economic development and poverty reduction in recipient countries. One major problem, they argue, is that the policies implemented by China often conflict with the plans of Organisation for Economic Co-operation and Development (OECD) countries to harmonise aid, and consequently increases the transaction costs for recipient countries (Kragelund 2008). Others focus on the aid-governance nexus, arguing that China's aid undermines good governance initiatives promoted by the West, and consequently leads to deepened debt and governance crises in Africa (Tull 2006; Chidaushe 2007; Schoeman 2007). Some further criticise China for the lack of accountability in its aid policies and its support for corrupt, chaotic and authoritarian regimes (Naim 2007). They argue that responsible and well-meaning organisations are being priced out of the African market, and that China's actions are showing neo-colonial tendencies (Manji and Marks 2007; Trofimov 2007).

Despite the above criticisms, several studies nonetheless argue that there is no reliable evidence to indicate that the arrival of major South-South cooperation providers, particularly China, has undermined governance standards (Paulo and Reisen 2010; Woods 2008). We believe that most current critiques of Chinese development assistance exaggerate the differences between China and others, particularly on the issue of good governance (Wissenbach 2010). Indeed, as Power et al. (2012) show, many of the supposedly negative interventions that China pursues are practised, or have been, by the 'established' donor countries of the global North. And some even question the extent to which OECD countries have successfully promoted better governance in Africa through the instrument of conditional aid (Mold 2009). Other analysts adopt an optimistic view by focusing on China's strategies and the growing opportunities for mutual learning and collaboration between all providers of development cooperation (Zimmermann and Smith 2011). Still other voices, including some from Africa, are more optimistic about China's role, claiming that traditional aid provided by the global North is inherently less effective than trade in promoting growth, and that important conditionalities (e.g. respect for human rights) are often overlooked by Western donors themselves. Since most aid is earmarked for governments, they argue that it encourages a large and ineffective public sector, which consequently thwarts private sector development. Aid is also claimed to discourage recipient governments from imposing fiscal and budgetary discipline. Government spending thus often exceeds domestic revenue, and the availability of aid encourages corruption, supports governments with 'bad' policies and discourages accountability. Thus, Moyo (2009) argues that the emergence of China provides Africa with a 'golden opportunity' to kick-start its development process.

More balanced perspectives categorise China as part of a wider group of 'emerging' donors (Manning 2006), even though some argue that the term 'emerging' is not appropriate (Zhou 2012) and that China and many others (that are deemed 'emerging') have been active donors for most of the Cold War period and beyond (King 2010). Moreover, these so-called emerging countries not only provide much needed financial capital to developing countries, but their activities have ushered in a 'salient revolution' as African political leaders believe that there is now a credible alternative to aid from established donors (Power et al. 2012: 129). Some studies also tend to focus on geopolitical and/or political economy perspectives, suggesting that foreign aid serves to address issues related to China's conflict (and competition) with Taiwan, that it negatively affects human rights in recipient countries and generates much needed access to natural resources for its ever-growing manufacturing industries.

We argue that a much-neglected feature of research on the topic is the general lack of appreciation for, and understanding of, the historical origins and cultural evolution of China's foreign aid based on its own developmental experiences. An important recent contribution to the debate has been the call by Scoones et al. (2013) to go beyond rhetorical claims in order to unearth the actual practices of development assistance, trade and investments, and identify and recognise innovative methods and practices. We argue that China's aid practices, although very different from established donor countries, must be viewed in relation to the international 


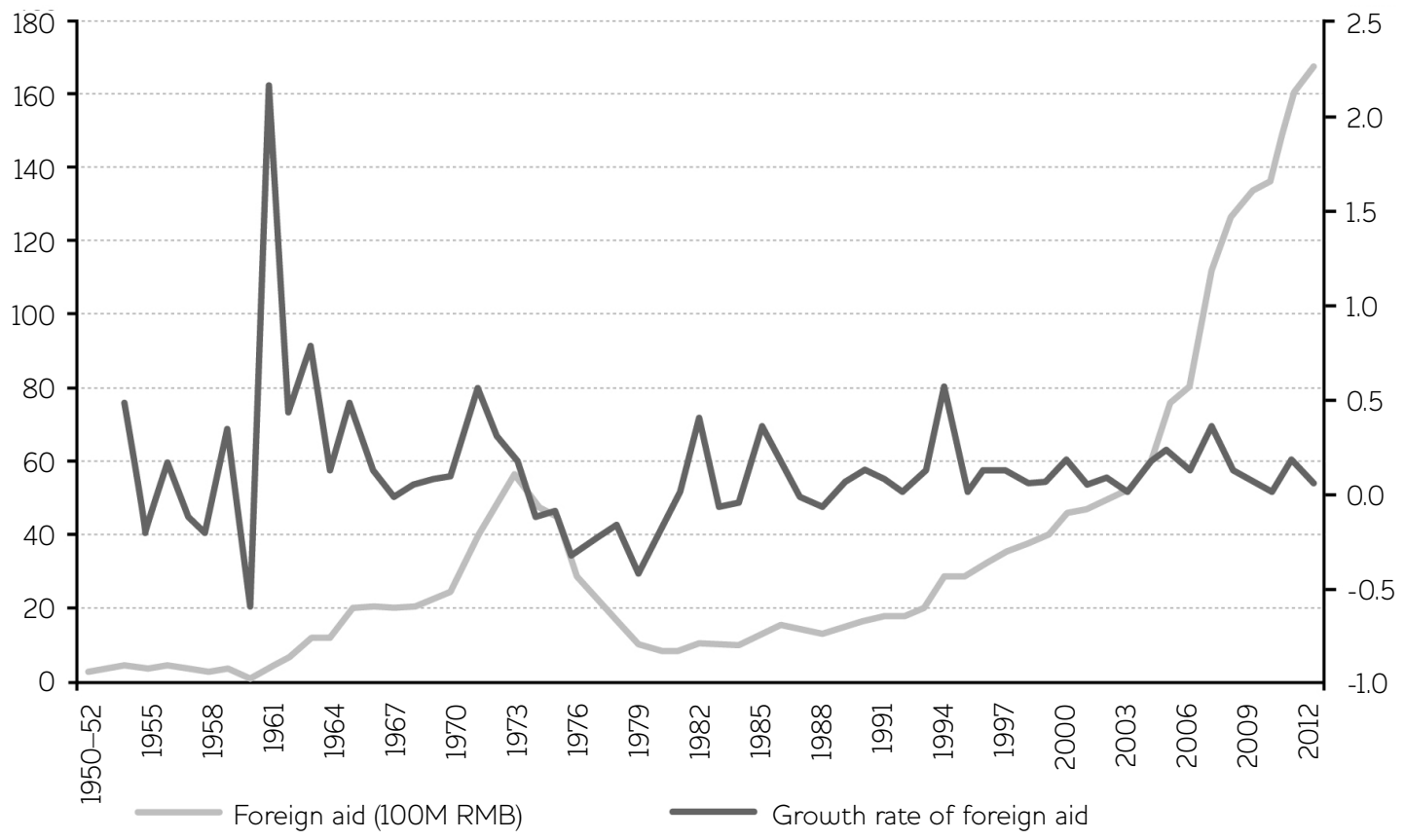

Source Authors' calculations based on the data from China Statistical Yearbook Series, China Statistical Press.

development context. Indeed, the need of the hour is an identification of common goals and concrete ways in which Western and Chinese aid can become a joint 'developmental force' on the ground in order to promote economic

development and reduce poverty in large parts of the developing world.

\section{Historical narratives of Chinese foreign aid: geopolitical instrument or alternative development extension?}

The period from 1950 until the end of the 1970s, during which foreign aid was considered an important means of supporting anti-colonial movements in developing countries, shaped much of China's current aid policies (Burke et al. 2007; Kjøllesdal and Welle-Strand 2010). A combination of economic and military support was initially provided, aimed at the liberation of oppressed nations. As Mao Zedong famously declared in June 1950, helping oppressed nations to become independent was the responsibility of the international community and an important communist obligation (Zhou 2012). Following the end of the Korean War and Vietnam's

independence, however, China began a period of providing aid for the post-war reconstruction of North Korea and Vietnam. Chinese assistance during this initial stage mainly focused on technical capacity development, infrastructure development and industrial and agricultural development (Shi 1989: 27-9). Concessional loans to these two countries were tied to the supply of materials, services, labour and equipment from China. This form of tied aid continues today, a practice that has often been highly criticised for perpetuating dependency. While the critique of tied aid raises numerous, and quite interesting concerns, it generally overlooks the fact that the tied-aid model was adopted mainly because China, during these early years, lacked foreign currency reserves and did not enjoy easy access to international markets. Another reason was the belief among Chinese leaders that the success of the international socialist experiment required developing countries to become aim towards selfreliance (Central Document Research Unit 1984: 383).

The existing geopolitical context of the Cold War certainly influenced China's foreign aid policy as it mainly pursued a policy of self-interest in the 1950 s in harnessing broad international support to consolidate and recognise its own independence, especially following deteriorating 


\begin{tabular}{lll}
\hline Categories & No. of projects supported & \% total \\
\hline $\begin{array}{l}\text { Agriculture and related sectors (farm, extension station, } \\
\text { agro-business) }\end{array}$ & 188 & 39 \\
Industry (textile, steel, etc.) & 88 & 18 \\
Infrastructure (road, railways) & 121 & 24 \\
Health, education and cultural facilities & 96 & 19 \\
\hline
\end{tabular}

Source Authors' calculation based on data from Shi (1989: 141-4).

relations with the Soviet Union. Subsequently, China's aid policies served broader interests, particularly in relation to its membership in the United Nations. For example, although the Republic of China (ROG) joined the UN in 1945, its membership obligations were performed by the ROC government in exile in Taiwan following the establishment of the People's Republic of China (PRC) in 1949. When the PRC was finally admitted in the UN in October 1971, many saw it as a result of China's successful foreign aid policies undertaken since the 1950s, claiming that 51 of the 76 countries that voted in favour of readmission had actually been recipients of Chinese foreign aid (Zhu 2011). Although it did help China's cause to cultivate friendly political relationships with as many developing countries as possible, Mao Zedong justified the continuation of aid as China's international obligation towards combating world poverty (Shi 1989: 14-15). It is also important to bear in mind that the major increase in Chinese aid occurred only after 1971 (see Figure 1).

The establishment of the PRC also marked the start of a developmental perspective in China's foreign policy as it highlighted the fight against imperialism and feudalism. Following extensive land reforms and the elimination of private ownership of land, there was also an improvement in the social status of women. Revolutions in Latin America and the growth of left-wing movements in Europe appeared to indicate that China had adopted the correct path to social and economic development. Moreover, social and economic progress achieved during the 1950s and 1960s convinced Chinese leaders that many of the newly independent countries in Asia and Africa could follow a similar developmental trajectory. Many Chinese leaders perceived the underdevelopment of China and other African and Asian countries to be the result of colonial and imperialist exploitation. They believed that with the right type of external support - just as China had initially benefited from Soviet support - rapid economic development was possible in poor countries.

Chinese assistance to other developing countries in the 1950s and until the 1970s reflected the country's own development experiences. This was particularly evident in the assistance it provided African countries for the development of state farms, state-owned textile companies and sugar and fertiliser factories. The narrative of Chinese agricultural aid to Africa thus demonstrated how China could usefully apply its own development experiences overseas.

As China's own development strategy prioritised agriculture, it also became a major focus of Chinese development assistance. And from the 1950 s to the 1970s, China supported a total of 496 projects in almost all fields of economic development in more than 50 countries in the world, 39 per cent of which was in the field of agriculture (see Table 1). During the 1970s, China expanded its agricultural technology support to Africa by dispatching around 670 agricultural experts to 25 African countries after Taiwan's assistance programmes were withdrawn. ${ }^{2}$

Over the years, China has actively advocated in Africa the so-called Dazhai model of agricultural development, which was pioneered in Dazhai village in China's Shanxi Province, and emphasises the organisation and training of farmers in small groups, and the large-scale application of labour for soil conservation. With a modest start in the Republic of Zaire in 1973, when Chinese agricultural experts applied the Dazhai model in the Ruzizi Reclamation Scheme 
Table 2 Regional distribution of foreign aid: China and DAC member countries, 2009

\begin{tabular}{lllllll}
\hline Regional distribution & Europe & Africa & Latin America & Asia & Oceania & Unspecified \\
\hline China & $0.30 \%$ & $45.70 \%$ & $12.70 \%$ & $32.80 \%$ & $4 \%$ & $4.50 \%$ \\
DAC member countries & $3.60 \%$ & $31.62 \%$ & $7.74 \%$ & $32.64 \%$ & $1.64 \%$ & $22.76 \%$ \\
Distribution by income & LDCs & Low-income & Low and & High and & Other \\
groups & & countries & middle-income & middle-income unspecified \\
& & & countries & countries & & \\
China & $39.70 \%$ & $23.40 \%$ & $19.90 \%$ & $11.00 \%$ & $6 \%$ \\
DAC member countries & $31.39 \%$ & $12.61 \%$ & $20.79 \%$ & $6.04 \%$ & $29.19 \%$ \\
\hline
\end{tabular}

Source Authors' calculation based on MOFCOM (2011) and OECD (http://stats.oecd.org/index.aspx).

and helped local governments to train more than 20,000 farmers in the country, the model was soon applied in Chinese-funded projects in other parts of Africa.

Although it has been commonly accepted that Chinese foreign aid largely served to further China's own political interests in the 1950s and 1960 s, the consolidation of agricultural aid to Africa is illustrative of a form of development assistance that has considerably benefited recipient countries, not least in promoting selfreliance. China learnt numerous lessons from the projects it supported from the 1950s and until the late 1970 s, many of which were not very successful in achieving their goals. For example, in the period 1971-5, China sent over 670 agricultural technical experts, invested over RMB 62 million for irrigation development and set up agricultural extension stations and farms in 25 African countries. Although the aim of this significant amount of aid was to promote selfreliance for food security in these countries, most projects did not achieve their goals (Jiang 2013). Several important lessons emerged, however, from these early experiments. First, it turned out that almost all projects involved the use of uncultivated land. Second, the projects organised farmers into cooperatives, where labour-intensive techniques were applied for infrastructure development. The goal of improving plant density and greater usage of farm manure were particularly successful (ibid.). However, due to various conditions, including water in poorly conditioned channels that evaporated at high temperature, the lack of large farm machines to undertake land reclamation, labour shortages, and the absence of local political interest, many otherwise successful projects could not be sustained. More importantly, Li et al. (2012) argue that the labour-intensive agricultural regime is not suitable to all African contexts. In addition to agricultural projects, a large number of stateowned aid projects, such as the China-Tanzania Friendship Textile Mill, have also failed.

Following the onset of economic reforms within China in 1978, there was a drastic decline in the volume of the country's foreign aid. Some observers have claimed that this major shift in policy was necessary for accelerating economic development within China (van de Looy and de Haan 2006). While economic difficulties within China definitely contributed towards this decline in overall aid, we find that the principles, upon which aid was based, remained unchanged, and there was a distinct policy shift to an aid effectiveness agenda with more emphasis on quality than simply on quantity. For example, in July 1979, Deng Xiaoping observed: 'Our past aid to Africa and Asia was the right thing to do... While we ourselves develop, it is strategically important to allocate substantial funds to aid other developing countries... we should not forget this principle... but we should try to ensure that recipient countries benefit from our aid' (quoted in Shi 1989: 70).

Throughout the 1980s, China consistently reflected back on its aid policies implemented since the 1950s, and generally concluded that such practices were largely inefficient, did not focus adequately on recipient countries' economic development and went beyond China's own capacity (Zhu 2011). As a result, major reforms were carried out in 1983 and 1993, and grandiose gifts made way for a set of diversified development programmes. Thus, the modalities 
of aid were expanded to include grants, zerointerest loans, concessional loans, and a marketbased framework, which encouraged joint ventures with developing country governments.

The decision to push forward a more businessoriented model of aid was a direct result of the failure of a large number of agricultural projects that China had supported over the years in Africa. For example, in the mid-1980s, the 'household responsibility system', which was widely used within China, was introduced in three rice farms in Burkina Faso. Within a couple of years after its introduction, these farms reported record yields and a dramatic increase in household income. As a result, this model was quickly applied by China in other African countries, including Rwanda, Ghana and Niger (Zhang 2013: 169-170).

Another failure that was turned into a success was the China-Tanzania Textile Mill project, which was developed in 1968 with an interest-free loan of RMB 70 million from China, but by 1992, was bankrupt, with debts of over US\$10 million. In 1995, China and Tanzania agreed to form a joint venture and the loan was converted into a 49 per cent share of the company, with the Chinese providing further resources for investment. The results since then have been quite impressive, and the new company has generated significant revenue and local employment opportunities.

While the Chinese aid model definitely has many unique features that distinguish it from those practised by Western donors, China has undertaken a series of reforms in the past decade to align its aid policies with global efforts. From the 1980 s to 1990 s, it began to explore a marketoriented model of aid while the West advocated an institutional reform model with a strong conditionality component. Since the 2000s, however, China has expressed greater interest in understanding the workings of multilateral institutions, and taken note of the commitments made in recent years at the UN High-Level Dialogue on Financing for Development and various UN meetings and events on the challenges of meeting the Millennium Development Goals. It has, moreover, established new financing mechanisms for multilateral efforts through Trust Funds (e.g. China-FAO Trust Fund for SouthSouth Cooperation) and entered into dialogues with major bilateral aid agencies, for example, through the China-UK and China-USA dialogues on international development. And in response to persistent criticisms of the lack of transparency in its aid policies, China has recently decided to publish white papers on aid (and annual reports have been promised in the near future) that provide greater details of allocations and priorities. Moreover, it has initiated learning activities, such as the OECD/DAC Study Group, which draws on the experiences of project evaluations of OECD members. Other recent examples are cooperation with DFID, Uganda and Malawi in agricultural development, and with New Zealand for water supply in the Cook Islands. Irrespective of whether one undertakes a comparison based on regional distribution of resources or targeted income groups that receive assistance, we believe that foreign aid from China and OECD countries share many common features, including a considerable share earmarked for Africa. It is also clear that the volume of aid disbursement to low-income countries by China is much higher than members of the OECD's Development Assistance Committee (see Table 2).

\section{4 'Conditionality' versus 'non-interference': different paths to development?}

One of the biggest debates concerning China's aid policies relates to its consistent emphasis of applying the principles of 'non-conditionality' and 'non-interference' in its foreign aid programme. By comparison, Western countries have a much longer tradition of intervening with the aim of promoting development in poorer regions of the world. However, while the Western aid framework aims for institutional transformation and improved political governance, the core principle of China's foreign aid programme has consistently been 'noninterference'. This principle derives primarily from China's long historical experience of dealing with foreign countries. The 'five principles of peaceful co-existence' - mutual respect for sovereignty and territorial integrity, mutual non-aggression, non-interference in each other's internal affairs, equality and mutual benefit, and peaceful co-existence - proposed by former Chinese Premier Zhou Enlai in 1953, continue to form the cornerstone of the country's foreign policy. These five principles were subsequently expanded into the so-called Eight Principles for Chinese foreign aid in January 1964, which continue to shape aid policies. ${ }^{3}$ 
By publicising the above principles, China signalled that it would neither accept political interference in its own affairs nor try to interfere in the affairs of the countries it assisted. The logic of the argument, articulated by Zhou Enlai in 1956, was that economic independence is a crucial prerequisite for political independence, and hence China ought to contribute towards promoting economic development in developing countries, while at the same time improving its own economic prospects (Wang 2012). There is thus an implicit argument here that economic development will have a catalytic change in terms of the quality and effectiveness of institutions. Chinese leaders further conveyed the message that they do not wish to preach on political strategies, preferring to make the case for economic development and self-reliance.

Accordingly, the official discourse has consistently highlighted 'experience sharing', a popular phrase that has its origins in a statement Zhou Enlai made while meeting his Ghanaian counterpart in 1964, and frequently used by successive Chinese leaders.

In its first white paper on foreign aid published in 2011, China reiterated that the principle of 'non-interference' formed the core of its policies, and that aid allocations were decided on 'the needs of recipient countries'. It has, however, not always been clear to scholars how, and to what extent, African countries actually make requests for development assistance to China and how officials in Beijing evaluate such requests. For example, China does not have specific 'country plans' and consequently does not undertake country-specific assessments of need. Rather, in response to China's domestic annual budget and/or visits by Chinese leaders and officials, Chinese embassies regularly carry out consultations with relevant agencies in recipient countries on the type of support that China can best provide. This is subsequently conveyed to Beijing, where the Ministry of Foreign Affairs first assesses the political aspects of the proposal before offering suggestions to the Ministry of Commerce (MOFCOM). The technical and financial aspects of the proposal are then assessed by MOFCOM.

The main criteria for evaluating proposals for potential aid projects are whether China can afford to support a project with adequate financial resources and technical expertise.
Chinese experts are often consulted, and field surveys may be commissioned before the government decides to initiate a bidding process. Although the bidding process is open, preference is usually given to those that wish to partner with credited entities at state and provincial levels (e.g. state enterprises, private enterprises and technical institutions). Most provinces are given so-called 'foreign aid tasks' and assigned 'matching partners' in African countries in order to collaborate with the central government in Beijing to fulfil China's international obligations. Such tasks may often require provincial subsidies. Thus, for example, in the field of medical assistance, Henan Province provides special assistance to Zambia and Eritrea while Hunan Province is matched with Zimbabwe and Sierra Leone. ${ }^{4}$ This process of decision-making is relatively simple and inexpensive, and differs considerably from the lengthier and expensive project cycles of typical aid projects funded by Western donors. However, unlike the systematic and complicated accountability system adopted by OECD-DAC members, China's foreign aid accountability is limited to the quality of 'construction', or 'output' rather than outcomes and impacts. As a direct result of its noninterference policy, China considers feasibility and impact as being the responsibility of recipients. It argues that development capacity can only be built through making mistakes or 'learning by doing'. Extensive external interference can prohibit 'agency' and reduce opportunity for recipients to learn by themselves. While intensive conditional assessments of feasibility and impact undertaken by Western donors are certainly important to ensure the quality of an intervention, the Chinese believe such actions are mainly aimed at documenting accountability within a Western donor's domestic political process. And systematic political, social and economic assessments would inevitably result in unavoidable conditionality, and thus China has favoured sending technical experts on deputation to African countries rather than offering political advice on matters of governance.

In order to address issues of project sustainability, however, the Chinese take a market-oriented approach assuming that foreign aid projects can be better sustained if mutual economic interests and incentives are applied. For example, the main purpose of the Agricultural Demonstration Centre at the Gwebi College of Agriculture in 
Zimbabwe, built in October 2011, is to transfer Chinese technology in agriculture to local farmers, demonstrating cultivation skills and carrying out agronomy trials. The centre consists of three separate units: a designated space for offices and accommodation of staff, another for training purposes, and a farm that is used to generate income for the long-term financial viability of the centre. When we visited this project site, we were surprised to observe that instead of hectic negotiations and meetings with local counterparts for implementing aid activities planned and defined by a logical framework, the project staff were selling potatoes, soyabean, wheat and maize and generally behaving like agro-businessmen. Many of the machines on display in the 'demonstration area' appeared unused. The project staff did not understand the concept of 'aid', and insisted that they were there for business. Indeed, the 'centre' resembled a private company and the leadership appeared very focused on acquiring additional land for potatoes and soyabean, with the aim of expanding the farming area from 74 to at least 600 hectares, which is what the centre had estimated to be the optimal size in order to be self-financing. The director complained that in the absence of adequate financial resources, he was not in a position to fulfil the wishes of his Zimbabwean counterpart, who wanted much more ambitious programmes for agricultural extension and training. Even when project funds were available from the Chinese government, these were limited to a three-year period, which meant that generating additional revenue was the only way in which the centre could continue its activity. For example, while China currently provides US $\$ 800,000$ for the period 2012-16, it expects the centre to explore a business-based model in order to secure its continued existence. By producing and selling agricultural products, the centre had, within a year, generated additional revenue of almost US $\$ 40,000$, which according to the director, significantly supplemented the centre's annual budget of approximately US $\$ 300,000$. There were also plans for setting up similar centres elsewhere in Zimbabwe.

When we visited another agricultural demonstration centre in Tanzania, we tried to identify project indicators, activities, outputs, outcomes and impact. However, the director insisted that his main priority was to lay a solid foundation for supplementary income generation, and for this purpose he wished to first establish a poultry farm. Such an approach would be unthinkable for most Western aid projects, and detailed empirical analyses are required in order to examine whether such revenue-generating strategies offer long-term sustainability for development projects. There is some evidence available, however, that multiple tasks that include farming and income generation, diverts such centres from undertaking more public services that can benefit the local population, and pose dilemmas regarding the main goal and purpose of the intervention (Li et al. 2012). We nonetheless believe that the practices that blur the boundaries between aid and business do indeed provide an interesting and alternative way of ensuring service delivery.

Consider the case of Malawi, which established formal diplomatic relations with China as recently as December 2007. From the very beginning, China has repeatedly asserted that it views itself as a 'development partner' and that the 'only purpose of China's presence... is to help Malawi achieve national development'. Similar statements are made on virtually every occasion the Chinese ambassador or his colleagues are invited to address a Malawian audience. And from available evidence, it appears that China has stuck closely to the clearly defined set of activities categorised under the four pillars on which it has based its aid to Malawi - infrastructure development; agriculture and food security; health and medical care; and education and human resources (Banik 2013). The Chinese message to various socio-political and economic actors in Malawi has moreover been that 'business is business' and that social and political stability is the key for healthy economic development. But while China has criticised European powers for not being consistent in condemning human rights abuses in the African continent (e.g. Ethiopia and Eritrea), available evidence suggests that China does indeed appreciate Malawi's support to the One China principle. Thus, there have been occasional references in the Chinese ambassador's speeches or on FOCAC website (usually a report on visiting dignitaries from Malawi to China or vice versa or speeches delivered at the launch ceremonies of specific projects) on how appreciative China is of Malawi's diplomatic support and firm commitments to the One China Policy and the cause of Chinese national 
reunification. On such occasions, it is nonetheless quite common for China to add that it 'respects Malawi's sovereignty and territorial integrity and its choice of national development path' (FOCAC 2010).

In Tanzania, we interviewed numerous actors, including government officials, involved in implementing the country's Agriculture First Strategy. The key perspective highlighted by most actors was the speed with which the Chinese government quickly agreed to the initial request and then built a modern Agricultural Technology Demonstration Centre within a span of 13 months after the cooperation agreement was signed. The project, which cost US\$7 million, did not involve complex negotiations and numerous visits by aid officials. The Tanzanian Ministry of Finance initiated a request to China for funding, while the Tanzanian government proposed a project site. Thereafter, a team from both countries jointly developed the design for the centre and construction was started soon after. Although the actual impact of this specific aid intervention on agricultural development and poverty reduction is yet to be empirically assessed, our respondents did not understand how such assistance could possibly undermine efforts by Western donors to promote good governance. Several people interviewed at the demonstration centres in both Tanzania and Zimbabwe observed that once there was agreement regarding the centre's location in consultation with government and local inhabitants, China sent a technical team to conduct a survey following which a design for the building structure was presented to the authorities. Once the authorities provided feedback on the proposed design, the Chinese speedily constructed the project, without transferring any money to the recipient government in order to avoid potential misuse of funds.

China thus insists on not questioning state legitimacy in its foreign aid policy, preferring to take a starting point in ground level realities in recipient countries. This is largely because China does not possess the institutional means available to Western donors (e.g. large NGOs with extensive contacts at local levels), and the only viable option is often to work with whichever political party that is currently in power. In doing so, China assumes that the recipient country government represents the country's interests, much like the role of the state in promoting development and human wellbeing is projected within China. Thus, the pro-state attitude, which constitutes an important part of China's own development image, is projected to development partners around the world. The idea of 'Africa' constructed by the Chinese government is one of 'needing help', but the recipients of such help are projected as 'partners' that enter into agreements of 'mutual interest'. This helps to legitimise China's foreign aid programmes as being intrinsically linked to Chinese culture, unlike the typical Western emphasis where help to Africa is relatively often justified on moral grounds.

Nonetheless, China is gradually realising the limitations of solely relying on the African state to achieve the developmental impacts of its aid. Increasingly, therefore, it has begun engaging with national and local civil society organisations within each African country. A more formalised platform for such engagement is being undertaken by the China-Africa Think Thank Forum, which consists of around 200 representatives from research institutes, NGOs and other civil society organisations from 30 African countries. There are also indications that China may encourage Chinese NGOs to participate in, and offer assistance on, aid programmes. Towards this end, we notice that numerous consultations have recently taken place between MOFCOM and Chinese NGOs. One recent example of such state-society collaboration is the China Poverty Foundation, which has developed health programmes in Sudan.

\section{Altrusim and 'mutual interest': from aid to development aid}

The 'Going-Out' strategy implemented since 2000 , and which is based on the principle of 'winwin' cooperation and mutual interests, constitutes a significant shift of Chinese foreign aid from being ideology-based to one based on economic realities (Brautigam 2008, 2009). Starting in the early 2000s, China's overseas economic activities began expanding rapidly, and following this, foreign aid expenditures increased correspondingly: from US $\$ 450$ million in 2000 to US $\$ 5.1$ billion in 2012 (see Figure 1). The government expressed greater support for international commitments to promote the MDG agenda in 2008. Towards this end, China has committed itself to building more than 30 agricultural technology demonstration centres in Africa, established a US\$30 million trust fund in 
the Food and Agricultural Organization (FAO) of the United Nations, and in accordance with the international development agenda, built over a hundred clean energy projects (e.g.

hydroelectricity, solar and biogas) in various parts of the developing world (Cui 2009; Diao and Zhang 2011). While China initially provided grants and non-interest loans to a large number of developing countries, it began to expand its concessional loan portfolio in the mid-1990s. Such loans were offered at 2-3 per cent interest rates over a 15-20 year period, which included a 5-7 year grace period. However, these practices do not constitute 'aid' as defined by OECD criteria of official development assistance, which defines concessionality on the basis of at least a 25 per cent grant element and 10 per cent discount rate. Nonetheless, Chinese concessional loans have been increasing, parallel to other development finance activities, such as the provision of export credit and incentives to Chinese companies to build overseas trade and enterprises. The lack of detailed data on disbursements and allocations to specific countries and sectors, however, adds to creating an impression that Chinese aid is purely based on economic returns that the country expects from aid-recipient countries. In reality, only the subsidies on concessional loan interest rates are counted in China's foreign aid budget, not the face value of loans or other development finance.

Since a large number of Chinese-funded projects in Africa from the 1950s until the 1970s failed to make an impact, and as a result, China decided to build infrastructural projects first, with manpower and equipment under its control, and then 'hand over' the projects to recipient countries, thus absolving itself from further responsibility related to project maintenance. It further began to encourage state and private sector actors in China to involve themselves in joint ventures with African business parties. Although many previously failed projects have now been successfully transformed into profitable businesses, the impact of the business model remains unclear and requires further research. The Sugar Complex Enterprises in Mali is an illustrative example in this context. In 1964, China helped Mali to develop a sugar factory and sugar cane farm located in Segou Region. In addition to providing equipment and technical support, China also funded the construction of the factory and the farm. The management of the enterprise was, however, left to the Malians. Unfortunately, the entire project was mismanaged and kept losing money, repeatedly verging on bankruptcy in the 1990s. In 1996, the Chinese and Malian governments agreed to form the China Light Industry Cooperation, a joint venture with 40 per cent Malian ownership. This transformation has helped the factory become the largest agrobusiness cooperation in Mali, with over 3,000 permanent staff and over 8,000 seasonal workers, and it currently contributes almost 30 per cent of domestic sugar production in the country.

Agricultural technology demonstration centres and joint venture businesses are two very different models of economic cooperation that China has explored over the past two decades. We believe that the future of these models requires a focus on two specific sets of issues. First, it remains unclear to what extent projects that are initially supported by China are sustainable once Chinese funding stops. Second, once funding from China stops, it is unclear how and to what extent China will wish to continue its economic cooperation. Thus, transforming 'obligation aid' (altruismrelated), which was practised before the 1980 s, to the current mutual interest-based aid presents key challenges to the future of evolution and continuity of the Chinese assistance package.

\section{Concluding remarks}

There is growing concern about the quality of development cooperation required for growth and effective poverty reduction, a feature that has received frequent global attention following the Monterrey International Conference on Financing for Development (2002). Over the past few decades, the focus of aid has also witnessed a gradual change from mainly economic growth-related goals to more social and environmentally sustainable development, with greater attention now on anti-corruption, democracy, human rights and gender equality.

The Accra Agenda for Action (2008) focused on the role and practices of emerging economies such as China, India and Brazil in providing aid, and reiterated the importance of the Paris principles (2005) of local ownership, alignment and harmonisation by urging both donor and recipient countries to demonstrate the impact of aid through more effective and inclusive partnerships. However, the ambitious agendas 
agreed in Paris and Accra did not provide quick and tangible results, and the predictability of aid flows continues to be a major problem. Indeed, many scholars and practitioners argue that the current aid system - dominated by numerous governmental and non-governmental agencies supported by Western donors - continues to appear dysfunctional, fragmented and duplicative.

\section{The Busan Partnership for Effective}

Development Cooperation (2011) aimed to address the changing aid architecture and established a framework that, in addition to traditional donors, also included emerging countries, civil society organisation and private funders. The signatories agreed on a two-tier approach (voluntary for emerging countries) to maintain a high level of political engagement on development issues, ensure greater accountability and support for implementing commitments, and facilitate sharing of knowledge and lessons learnt. An important step forward has been made to shift the aid effectiveness agenda to one of development effectiveness, which in turn has provided room to accommodate alternative approaches practised not only by China, but also by other development actors. The modalities for achieving effective results aimed at rapid poverty reduction, however, remain unclear.

In this article, we have argued that the modalities of China's development assistance have been developed historically and socioculturally. With a focus on South-South

\section{Notes}

* We would like to acknowledge the following sources of funding: UK Economic and Social Research Council for funding the case studies in Zimbabwe under the China and Brazil in African Agriculture (CBAA) project; and the Research Council of Norway for funding fieldwork in Malawi.

1 There are very few studies on Chinese aid to Africa before the year 2000. Some notable exceptions are Eadie and Grizzell (1979) and Ping (1999). For research on the topic after 2005, see Glosny (2006), Alden (2007), Lancaster (2007), Davies (2007), Woods (2008), Paulo and Reisen (2010), Kjøllesdal and WelleStrand (2010) and Power et al. (2012).

2 From 1970, the Chinese decided to increase aid to Africa under two political agendas. The first was to cultivate political alliances in Africa to cooperation, China has provided an alternative aid paradigm that has the potential of making a major difference to how developing countries pursue their own development strategies. However, given the radical increase in the volume of its development assistance in recent years, China faces numerous challenges in ensuring that its efforts complement those of the international development community.

The evolution of the 'self-learning' brand of Chinese foreign aid, as we have discussed in this article, has been multidimensional - drawn heavily on the lessons from past failures, China's own domestic development experiences and lessons learnt from Western aid practices and development experiences. China's 'noninterference' policy is aimed at promoting local ownership and the focus on the 'mutual interest' approach has documented results in promoting development effectiveness via the aid-business-trade model. We believe that there is ample evidence currently available that supports our argument that the typical and popularised view in the Western media and scholarship regarding the divergent goals of China and the West are largely unfounded. Rather, we have argued that despite very different historical and political contexts, the major actors of development aid, including China, share a common goal of global development and poverty reduction, which in turn provides adequate room for convergence of a varied set of interests.

counterbalance the United States and the Soviet Union. The second agenda entailed seeking support for its 'One China Policy', which meant that China began challenging Taiwan's well-established agricultural aid packages that, with the help of the United States, had been active in more than 30 African countries since the early 1960s.

3 The Eight Principles included the following: equality and mutual benefit in providing aid to other countries; respect for the sovereignty of recipient countries; provision of economic aid in the form of interest-free or low-interest loans; promotion of self-reliance and independent economic development; priority to projects that require less investment but fast results; provision of high-quality equipment and materials manufactured by China at international market prices; transfer 
of skills and technology to recipient countries; provision of technical and practical expertise by visiting Chinese experts.

4 For a complete list, see Li (2009).

5 China's ambassador to Malawi, remarks at the Welcome Dinner hosted by MISA Malawi,

\section{References}

Alden, C. (2007) China in Africa, London: Zed Books

Banik, D. (2013) 'China and Poverty Reduction in Africa', in G. Yu (ed.), Rethinking Law and Development: The Chinese Experience, London: Routledge

Brautigam, D. (2009) The Dragon's Gift: The Real Story of China in Africa, Oxford: Oxford University Press

Brautigam, D. (2008) 'China's Foreign Aid in Africa: What do we Know?', in R.I. Rotberg (ed.), China into Africa: Trade, Aid, and Influence, Washington DC: Brookings Institution Press

Burke, C.; Corkin, L. and Tay, N. (2007) China's Engagement of Africa: Preliminary Scoping of African Case Studies. Angola, Ethiopia, Uganda, South Africa, Zambia, Stellenbosch: Centre for Chinese Studies, University of Stellenbosch

Central Document Research Unit (1984) Zhou Enlai's Work, Beijing: People's Press: 383

Chidaushe, M. (2007) 'China's Grand Reentrance into Africa - Mirage or Oasis?', in F. Manji and S. Marks (eds), African Perspectives on China in Africa, Cape Town: Fahamu

Cui, P. (2009) 'China Pledged 6 Commitments to Aid Developing Countries', People Daily, 22 September, B03, http://paper.people.com.cn/ rmrb/html/2009-09/22/content_347907.htm (accessed 3 February 2014)

Davies, P. (2007) China and the End of Poverty in Africa - Towards Mutual Benefit?, Sundbyberg: Diakonia

Diao, C. and Zhang, L. (2011) 'China's Hydroelectricity would Light Africa', China Economic Herald, 2 July: B02, www.ceh.com.cn/ ceh/cjxx/2011/7/2/81804.shtml (accessed 3 February 2014)

Eadie, G.A. and Grizzell, D.M. (1979) 'China's Foreign Aid, 1975-78', China Quarterly 77: 217-34 FOCAC (2010) China's Top Legislator Meets Malawian Counterpart, www.focac.org/eng/zfgx/ t779859.htm (accessed 30 April 2012)

Glosny, M.A. (2006) China's Foreign Aid Policy: Lifting States out of Poverty or Leaving Them to the Dictators, Washington DC: Center for Strategic and International Studies
23 March 2011, http://mw.chinaembassy.org/eng/dsxx/dsjh/t809057.htm (accessed 30 May 2012).

Jiang, H. (2013) 'Agricultural Technology Aid to Africa (1971-1983): Case Study of China's Aid to Africa Model and Result', (农技援非 1971-1983)中国援非模式与成效的, 个案研究), Foreign Affair Review (外交评论) 1: 30-49

King, K. (2010) 'New Actors: Old Paradigms?', in K. King (ed.), A Brave New World of 'Emerging', 'Non-DAC' Donors and their Differences from Traditional Donors, NORRAG News 44, September, www.norrag.org/es/publications/ boletin-norrag/online-version/a-brave-newworld-of-emerging-non-dac-donors-and-theirdifferences-from-traditional-donors/detail/ editorial-new-actors-old-paradigms-1.html (accessed 5 February 2014)

Kjøllesdal, K. and Welle-Strand, A. (2010) 'Foreign Aid Strategies: China Taking Over?', Asian Social Science 6.10: 3-12

Kragelund, P. (2008) 'The Return of Non-DAC Donors to Africa: New Prospects for African Development?', Development Policy Review 26.5: 555-84

Lancaster, C. (2007) The Chinese Aid System, Washington DC: Center for Global Development, www.cgdev.org/files/13953 file_Chinese_aid.pdf (accessed 25 February 2013)

Li, X. (2009) 'The History, Scaling and Impacts of China's Medical Assistance', Foreign Affairs Review 1: 25-45

Li, X.; Qi, G.; Tang, L.; Zhao, L.; Jin, L.; Guo, Z. and Wu, J. (2012) Agricultural Development in China and Africa: A Comparative Analysis, London: Routledge

Manji, M. and Marks, S. (eds) (2007) African Perspectives on China in Africa, Cape Town: Fahamu

Manning, R. (2006) 'Will "Emerging Donors" Change the Face of International Cooperation?', Development Policy Review 24.4: 371-85

MOFGOM (2011) White Paper on China Aid, http://english.gov.cn/official/2011-04/21/ content_1849913.htm (accessed 29 November 2012)

Mold, A. (2009) Policy Ownership and Aid Conditionality in the Light of the Financial Crisis: 
A Critical Review, Paris: OECD Development Centre

Moyo, D. (2009) Dead Aid: Why Aid is not Working and how there is a Better Way for Africa, New York: Farrar, Straus and Giroux

Naim, M. (2007) 'Rogue Aid', Foreign Policy 159: 95-6

OECD (n.d.) OECD StatExtracts Database, http://stats.oecd.org/index.aspx (accessed 4 May 2013)

Paulo, S. and Reisen, H. (2010) 'Eastern Donors and Western Soft Law: Towards a DAC Donor Peer Review of China and India?' Development Policy Review 28.5: 535-52

Ping, A. (1999) 'From Proletarian

Internationalism to Mutual Development:

China's Co-operation with Tanzania, 1965-95', in G. Hyden and R. Mukadala (eds), Agencies in Foreign Aid: Comparing China, Sweden and the United States in Tanzania, Basingstoke: Macmillan

Power, P.; Mohan, G. and Tan-Mullins, M. (2012) China's Resource Diplomacy in Africa: Powering Development?, Hampshire: Palgrave Macmillan

Schoeman, M. (2007) 'China in Africa: The Rise of a Hegemony', China and Africa: Partners in Development and Security?, Copenhagen: Danish Institute of International Affairs

Scoones, I.; Cabral, L. and Tugendhat, H. (2013) 'New Development Encounters: China and Brazil in African Agriculture', IDS Bulletin 44.4: 1-19

Shi, L. (1989) Contemporary China's Foreign Economic Cooperation (当代中国的对外经济 合作) Beijing: Chinese Social Science Press (中国社会科学出版社)

Trofimov, Y. (2007) 'New Management: In Africa China's Expansion Begins to Stir Resentment: Investment Boom Fuels Colonialism Charge; A Tragedy in Zambia', The Wall Street Journal, 2 February
Tull, D. (2006) 'China's Engagement in Africa: Scope, Significance, and Consequences', Journal of Modern African Studies 44.3: 459-79

Van de Looy, J. and de Haan, L. (2006) 'Africa and China: A Strategic Partnership?' Strategic Analysis 30.3: 562-75

Wang, M. (2012) 'The Rationale of China's Eight Principles for Economic and Technical Cooperation' (中国对外经济技术援助八项原则的提出) Centennial Wave(百年潮) 1: 66-8

Wissenbach, U. (2010) 'A New Seoul Consensus on Development? The G20 Needs to Reconcile Effective ODA with Emerging Country Economic Cooperation', in T. Fues and P. Wolff (eds), G20 and Global Development: How Can the New Summit Architecture Promote Pro-Poor Growth and Sustainability?, Bonn: German Development Institute

Woods, N. (2008) 'Whose Aid? Whose Influence? China, Emerging Donors and the Silent Revolution in Development Assistance', International Affairs 84.6: 1205-21

Zhang, J. (2013) 'China's Aid to Africa', in H. Zhou and H. Xiong (eds), Six Decades of China's Foreign Aid (中国援外60 年) Social Sciences Academic Press (社会科学文献 出版社) 169-70

Zhou, H. (2012) 'China's Evolving Aid Landscape: Crossing the River by Feeling the Stones', in S. Chaturvedi, T. Fues and E. Sidiropoulos (eds), Development Cooperation and Emerging Powers, London: Zed Books

Zhu, R. (2011) 'Historical Evolution of Chinese Communist Party's Foreign Policy', Mao Zedong and Deng Xiaopin Studies 9: 71-84

Zimmermann, F. and Smith, K. (2011) 'More Actors: More Money, More Ideas for International Development Co-operation', Journal of International Development 23.5: 722-38 